\title{
EVALUASI PEMBELAJARAN PRAKTEK SENI KRIYA PAYET SARUNG BANTAL KURSI PADA PROGRAM STUDI TATA BUSANA UNIVERSITAS NEGERI MEDAN
}

\author{
Netty Juliana \\ (Dosen Jurusan Pendidikan Kesejahteraan Keluarga)
}

\begin{abstract}
ABSTRAK
Pendekatan yang digunakan dalam penelitian ini adalah penelitian kuantitatif. Dengan menggunakan skala Likert dimodifikasi dengan indikator pengukuran skala efektifitas model yang telah dirancang dan telah diterapkan dalam proses pembelajaran. Penelitian ini bertujuan untuk mengungkapkan bagaimana "Evaluasi Pembelajaran Praktek Seni Kriya Payet Sarung Bantal Kursi Pada Program Studi Tata Busana Universitas Negeri Medan". Analisis data menunjukkan bahwa 1) Konsep Perancangan Seni Kriya Payet sarung bantal kursi Pada Program Studi Tata Busana Unimed dengan persentase 71\%. 2) Prinsip-Prinsip Desain Pada Kreasi Motif Khas Sumatera Utara pada pembelajaran praktik seni kriya dengan presentase 71\%. 3) Sketsa Gambar Motif masuk kategori sedang dengan presentasi 77 \%. 4) Kertas Gambar untuk Master Desain motif Sumatera Utara termasuk kategori sedang dengan presentasi 75\%. 5) Pewarnaan Pada Master Desain masuk katergori tinggi dengan presentasi 80\%.6) hasil Gambar Motif Kreasi Sumatera Utara pada Bahan Dasar Kain termasuk kategori sedang dengan presentase 75\%. 7) Material Dasar Kain Pada Pembuatan Kriya Tekstil Payet masuk ketegori sangat sedang dengan presentasi 76\%. 8) Bahan Payet Pada Pembuatan Kriya Tekstil Sumatera Utara termasuk kategori tinggi dengan presentase $81 \%$. 9) Pengaplikasian Jenis-Jenis Payet Pada Bahan Dasar Kain termasuk kategori sangat tinggi dengan presentase 81\%. Dan 10) Hasil Kreatifitas Mahasiswa Pembuatan Prodak kriya payet Sarung Bantal Kursi kategori tinggi dengan presentase $84 \%$. Maka pengembangan pembelajaran praktek seni kriya payet pada lenan rumah tangga khususnya sarung bantal baik untuk mahasiswa guna mempersiapkan keterampilan dan pengetahuan dalam berwirausaha membuka lapangan kerja, seperti home industri.
\end{abstract}

\section{Keywords: Pembelajaran, Praktek, Seni Kriya Payet, Sarung Bantal Kursi}

\section{PENDAHULUAN}

Pembelajaran pada hakekatnya merupakan proses interaksi antara siswa dengan lingkungannya, sehingga terjadi perubahan perilaku ke arah lebih baik. Selama proses pembelajaran, tugas guru yang paling utama adalah mengkondisikan lingkungan belajar agar menunjang terjadinya perubahan perilaku bagi siswa (E.Mulyasa, 2003).

Menurut Gagne sebagaimana yang telah dikemukakan oleh Nazarudin (2007:162) pembelajaran dapat diartikan sebagai seperangkat acara peristiwa eksternal yang dirancang untuk mendukung proses belajar yang sifatnya internal. Menurut Nazarudin (2007:163) pembelajaran adalah suatu peristiwa atau situasi yang sengaja dirancang dalam rangka membantu dan mempermudah proses belajar dengan harapan dapat membangun kreatifitas siswa.

Bila diamati selama ini pembelajaran praktik seni kriya payet selalu diaplikasikan pada busana wanita secara manual dengan media jarum tangan dan benang jahit. Sebelum proses memayet dilakukan diatas permukaan kain, terlebih dahulu dilakukan membuat pola gambar sesuai dengan konsep yang diinginkan oleh desainer. Proses memayet ini merupakan bagian dari suraface design atau disebut desain permukan. Surface design adalah rancangan motif atau ragam hias dilakukan diatas permukaan kain polos, sehingga kain tersebut memiliki nilai seni keindahan bagi konsumen.

Maka peneliti melakukan pengembangan pembelajaran praktik seni 
kriya payet pada lenan rumah tangga yaitu sarung batal kursi tamu dengan mengembangan desain motif khas Sumatera Utara. Proses pembuatan seni kriya memayet masih dilakukan secara manual yaitu; 1) membuat pola diatas permukaan kain polos, 2) menjahit berbagai jenis payet dengan menggunakan jarum tangan, 3) melakukan finishing prodak dengan menggunakan mesin jahit manual. Dengan ini mahasiswa mampu menciptakan prodak sarung bantal kursi tamu bermotif etnik Sumatera utara dengan inovatif, kreatif, dan mandiri.

Untuk itu pembelajaran praktik seni priya payet sarung bantal kursi pada program studi tata busana universitas negeri Medan merujuk pada literature tersebut, maka peneliti mengembangkan instrument penelitian untuk mengukur keterampilan Pengembangan Mendesain seni kriya payet pada sarung bantal kursi tamu yakni; 1) Konsep Perancangan seni kriya tekstil payet pada Sarung bantal kursi, 2) Prinsip-Prinsip Desain Pada Kreasi Motif Khas Sumatera Utara, 3) Sketsa Gambar Motif, 4) Kertas Gambar untuk Master Desain motif Sumatera Utara, 5) Pewarnaan Pada Master Desain, 6) Gambar Motif Kreasi Sumatera Utara pada Bahan Dasar Kain, 7) Material Dasar Kain Pada Pembuatan Kriya Tekstil Payet, 8) Bahan Payet Pada Pembuatan Kriya Tekstil Sumatera Utara, 9) Pengaplikasian JenisJenis Payet Pada Bahan Dasar Kain, 10) Pembuatan Prodak Sarung Bantal Kursi, dan 11) Hasil Kreatifitas Mahasiswa Pada Prodak Kriya Sarung Bantal Kursi.

Pembelajaran praktik merupakan suatu proses untuk meningkatkan keterampilan peserta didik dengan menggunakan berbagai metode yang sesuai dengan keterampilan yang diberikan dan peralatan yang digunakan. Selain itu, pembelajaran praktik merupakan suatu proses pendidikan yang berfungsi membimbing peserta didik secara sistematis dan terarah untuk dapat melakukan suatu ketrampilan.

Pratikum berasal dari kata praktik yang artinya pelaksanaan secara nyata apa yang disebut dalam teori. Sedangkan pratikum adalah bagian dari pengajaran yang bertujuan agar siswa

\section{KAJIAN PUSTAKA}

Pembelajaran praktik merupakan suatu proses untuk meningkatkan keterampilan peserta didik dengan menggunakan berbagai metode yang sesuai dengan keterampilan yang diberikan dan peralatan yang digunakan.

Semendapat kesempatan untuk menguji dan melaksanakan di keadaan nyata, apa yang diperoleh dari teori dan pelajaran praktik (KBBI, 2001:785). Melalui praktikum, peserta didik dapat memiliki banyak pengalaman, baik berupa pengamatan langsung atau bahkan melakukan percobaan sendiri dengan objek tertentu. Tidak diragukan lagi bahwa melalui pengalaman langsung (first-hand experiences), peserta didik dapat belajar lebih mudah dibandingkan dengan belajar melalui sumber sekunder, misalnya buku. Hal tersebut sangat sesuai dengan pendapat Bruner yang menyatakan bahwa anak belajar dengan pola inactive melalui perbuatan (learning by doing) akan dapat mentrasnfer ilmu pengetahuan yang dimilikinya pada berbagai situasi (Tresna Sastrawijaya, 1998 : 17).

payet merupakan benda kecil yang bisa memberi arti besar apabila diperlakukan dengan sentuhan sulam dari tangan terampil. Namun, tidak semua orang menganggap kegiatan menyulam payet ini mudah dilakukan.

Aksesoris payet adalah salah satu manik-manik yang berbentuk pipih dan berukuran kecil yang biasa digunakan untuk menghias baju atau pakaian sebagai pelengkap untuk keindahan busana. Sulaman yang dibuat menggunakan tangan ini, di Indonesia pertama kali di buat oleh kerajaankerajaan yang berada di Nusantara. Sebagai kebudayaan yang harus dilestarikan yang biasanya digunakan dalam acara adat atau acara formal dengan menggunakan busana yang berpayet. Pada jaman dahulu aksesoris payetan digunakan pada pakaian adat daerah sebagai symbol untuk upacara adat desa setempat saja. Namun pada abad ke 21 ini banyak suatu perancangan baju atau fashion yang sangat pesat dan signifikan 
menggunakan payet sebagai aksesoris utamanya.

Dengan menggunakan hiasan bahan payet dan manik-manik, dapat menjadikan suatu karya yang dihasilkan oleh desainer aksesoris kreatif mampu mendatangkan keuntungan tinggi bila dibandingkan dengan pembuatan bahan tanpa diberi aksesoris payetan. Dalam penggunaanya, aksesoris payet biasanya digunakan dalam sebuah acara formal. Namun pada saat ini aksesoris payet sangat dibutuhkan dan amat penting digunakan dalam setiap gaun atau busana apapun sebagai pelengkap keindahan busana.

Payet yang sering digunakan di Indonesia diantaranya, payet padi, tebu, lombok, pasir, piring dan lain-lain sebagai penghias busana. Berawal dari percobaan bahan dan eksperimen inilah payetan dapat dijadikan kreasi yang sangat menarik yang semakin berkembang dan tidak punah sampai di masa modern ini. Pemakaian payet dapat membuat penampilan seseorang menjadi lebih elegan dan terkesan indah, tanpa mengeluarkan banyak modal. Untuk membuat aksesori payet, dibutuhkan beberapa bahan, antara lain: benang, kain, benang, payet, dan jarum (Anthin Lathifah, 2015)

Kriya dalam konteks masa lampau dimaknai sebagai suatu karya seni yang unik dan karakteristik yang di dalamnya mengandung muatan nilai estetik, simbolik, filosofis dan fungsional serta ngrawit dalam pembuatannya (Gustami SP).

Seni Kriya ialah suatu cabang seni

yang kegiatannya berlandaskan pada tradisi dengan didukung oleh keahlian

(ketrampilan/keprigelan) dalam

menggunakan alat yang menjadi ciri dari

proses pembuatan bendanya (Muria)

Sarung bantal adalah tempat untuk melindungi bantal dari debu atau kotoran. Sarung bantal kursi digunakan sebagai hiasan pada kursi atau untuk melengkapi kursi tamu atau kursi keluarga dengan bantal dari berbagai bentuk,warna dan ukuran. Fungsi sarung bantal padakursi yaitu :1) Memperindah penampilan kursi, 2) Menambah kenyamanan seseorang pada waktu duduk, 3) Melindungi dari debu dan kotoran lain.

\section{METODE PENELITIAN}

Penelitian ini menggunakan pendekatan deskriptif kuantitatif untuk menganalisis bagaimana kemampuan untuk melakukan pengembangan pembelajaran praktek, khususnya pembuatan prodak batik tulis pada mata kuliah Seni kriya Payet sarung bantal kursi pada Mahasiswa program studi tata busana di Unimed pada tahun akademik 2016.

Populasi dan sampel penelitian adalah mahasiswa Jurusan Tata Busana Unimed tahun akademik 2016 berjumlah 120 orang, dengan pertimbangan bahwa mahasiswa yang diteliti adalah mahasiswa yang mengikuti perkuliahan seni kriya memayet.

Berdasarkan teknik sampling purposive dan teknik Slovin dalam pengambilan sampel maka diketahui bahwa jumlah adalah 30 orang. Untuk mengumpulkan data penelitian dilakukan dengan menggunakan instrument kuesioner (angket). Angket disusun dan dikembangkan sesuai dengan indikator 10 variabel kemampuan yang diperlukan dipasar kerja, indikator kemudian disusun berdasarkan kajian teori yang dikemukakan para ahli yang kemudian dikembangkan menjadi pertanyaan-pertanyaan. Dengan menggunakan Skala Likert yang dimodifikasi sesuai dengan indikator pengukuran dengan skala pengukuran efektifitas model yang telah dirancang dan telah diterapkan dalam proses pembelajaran.

Analisis data dilakukan dengan teknik persentase dan pengkategorian dengan rumus:

Total perolehan skor

Jawaban tertinggi $\mathrm{x}$ Jumlah responden $\mathrm{x}$ Jumlah soal

Hasil analisis berdasarkan rumus di atas kemudian dilakukan pengkategorian terhadap hasil tingkat pencapaian Responsen berdasarkan skala. Sudjana (1996) sesuai tabel 1 berikut ini: 
Tabel 1: Skala Kriteria

\begin{tabular}{|l|l|}
\hline Persentase Pencapaian & Kriteria \\
\hline $90-100 \%$ & Sangat tinggi \\
\hline $80-89 \%$ & Tinggi \\
\hline $65-79 \%$ & Sedang \\
\hline $55-64 \%$ & Rendah \\
\hline $0-54 \%$ & Sangat Rendah \\
\hline
\end{tabular}

\section{HASIL DAN PEMBAHASAN}

Hasil penelitian diuraikan berdasarkan nilai rata-rata (mean), nilai tengah (median), nilai terendah (minimum), nilai tertinggi (maximum), total nilai (sum), persentase tingkat pencapaian responden dan kategorinya. Berikut ini hasil analisis data evaluasi Pembelajaran Praktek seni kriya memayet sarung bantal kursi pada Mahasiswa pada Pendidikan Tata Busana Universitas Negeri Medan tahun 2016.

Tabel 2: Hasil Analisis Data
Payet Sarung Bantal Kursi Pada Program Studi Tata Busana Universitas Negeri Medan" yang masuk kategori sedang Evaluasi Konsep Perancangan Seni Kriya Payet sarung bantal kursi Pada Program Studi Tata Busana Universitas Negeri Medan dengan persentase $71 \%$. Hasil Prinsip-Prinsip Desain Pada Kreasi Motif Khas Sumatera Utara pada pembelajaran praktik seni kriya masuk kategori sedang dengan presentase 71\%. Hasil Sketsa Gambar Motif terhadap pembelajaran seni kriya masuk kategori sedang dengan presentasi $77 \%$. Hasil evaluasi Kertas Gambar untuk Master Desain motif Sumatera Utara terhadap pembelajaran praktik seni kriya termasuk kategori sedang dengan presentasi 75\%. Evaluasi Pewarnaan Pada Master Desain pada pembelajaran seni kriya masuk katergori tinggi dengan presentasi $80 \%$. Hasil evaluasi Gambar Motif Kreasi Sumatera Utara pada Bahan Dasar Kain dalam pengajaran seni kriya termasuk kategori sedang dengan presentase $75 \%$. Hasil Material Dasar Kain Pada Pembuatan Kriya Tekstil Payet selama pembelajaran praktik seni kriya masuk ketegori sangat sedang dengan presentasi $76 \%$. Hasil Bahan

\begin{tabular}{|c|c|c|c|c|c|c|c|c|c|}
\hline No & Hasil Evaluasi Pembelajaran & Mean & Mdi & Mode & Min & Max & Sum & $\%$ & Kategori \\
\hline 1 & $\begin{array}{l}\text { Konsep Perancangan Seni Kriya } \\
\text { Payet sarung bantal kursi }\end{array}$ & 35,37 & 37 & 37 & 21 & 50 & 1061 & $71 \%$ & Sedang \\
\hline 2 & $\begin{array}{l}\text { Prinsip-Prinsip Desain Pada } \\
\text { Kreasi Motif Khas Sumatera } \\
\text { Utara }\end{array}$ & 35,33 & 37 & 39 & 19 & 50 & 1060 & $71 \%$ & Sedang \\
\hline 3 & Sketsa Gambar Motif & 38,63 & 39 & 41 & 25 & 50 & 1159 & $77 \%$ & Sedang \\
\hline 4 & $\begin{array}{l}\text { Kertas Gambar untuk Master } \\
\text { Desain motif Sumatera Utara }\end{array}$ & 37,53 & 37 & 36 & 22 & 50 & 1126 & $75 \%$ & Sedang \\
\hline 5 & Pewarnaan Pada Master Desain & 44,17 & 45 & 45 & 32 & 55 & 1325 & $80 \%$ & Tinggi \\
\hline 6 & $\begin{array}{l}\text { Gambar Motif Kreasi Sumatera } \\
\text { Utara pada Bahan Dasar Kain }\end{array}$ & 37,40 & 36 & 31 & 30 & 50 & 1122 & $75 \%$ & Sedang \\
\hline 7 & $\begin{array}{l}\text { Material Dasar Kain Pada } \\
\text { Pembuatan Kriya Tekstil Payet }\end{array}$ & 38,13 & 38 & 40 & 30 & 50 & 1144 & $76 \%$ & Sedang \\
\hline 8 & $\begin{array}{l}\text { Bahan Payet Pada Pembuatan } \\
\text { Kriya Tekstil Sumatera Utara }\end{array}$ & 40,33 & 41 & 50 & 28 & 50 & 1210 & $81 \%$ & Tinggi \\
\hline 9 & $\begin{array}{l}\text { Pengaplikasian Jenis-Jenis Payet } \\
\text { Pada Bahan Dasar Kain }\end{array}$ & 40,27 & 40 & 38 & 28 & 50 & 1208 & $81 \%$ & Tinggi \\
\hline 10 & $\begin{array}{l}\text { Hasil Kreatifitas Mahasiswa } \\
\text { Pembuatan Prodak kriya payet } \\
\text { Sarung Bantal Kursi }\end{array}$ & 42,23 & 41 & 40 & 29 & 50 & 1267 & $84 \%$ & Tinggi \\
\hline
\end{tabular}

Payet Pada Pembuatan Kriya Tekstil Sumatera Utara dalam pembelajaran praktik

Tabel 2 diatas menunjukkan hasil evaluasi "Evaluasi Pembelajaran Praktek Seni Kriya

kriya termasuk kategori tinggi dengan 
presentase $81 \%$. Evaluasi Pengaplikasian Jenis-Jenis Payet Pada Bahan Dasar Kain selama pembelajaran praktik seni kriya termasuk kategori sangat tinggi dengan presentase $81 \%$. Dan evaluasi Hasil Kreatifitas Mahasiswa Pembuatan Prodak kriya payet Sarung Bantal Kursi mahasiswa pada tahun 2016 pada pembelajaran seni kriya payet tulis masuk kategori tinggi dengan presentase $84 \%$.

Analisis data yang dikemukakan, lebih jelas dapat dikemukakan hasil penelitian dalam bentuk histrogram berikut ini:

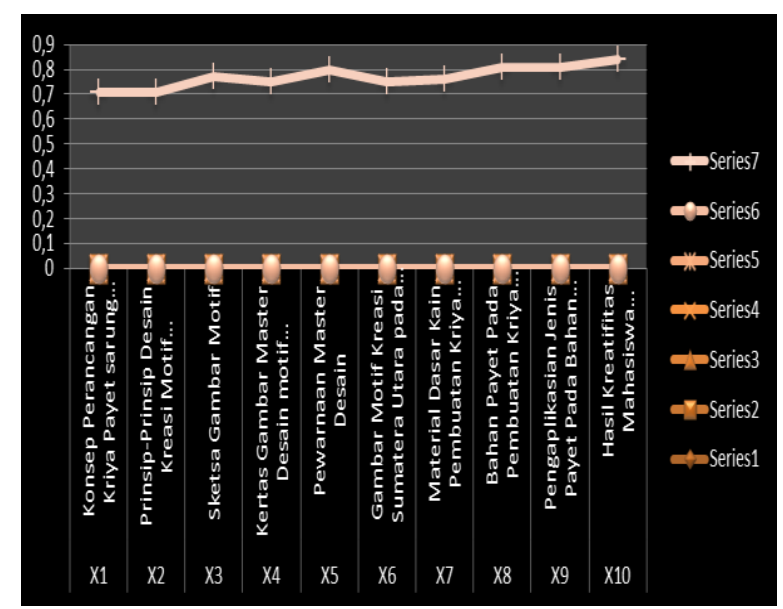

Berdasarkan analisis data yang diuraikan pada data tabel dan gambar histrogram diatas menjelaskan bahwa pembelajaran praktek seni kriya payet Sarung Bantal Kursi Pada Program Studi Tata Busana Universitas Negeri Medan mempunyai beberapa indikator yakni; 1) Konsep Perancangan Kriya Payet sarung bantal kursi, 2) PrinsipPrinsip Desain Pada Kreasi Motif Khas Sumatera Utara, 3) Sketsa Gambar Motif, 4) Kertas Gambar untuk Master Desain motif Sumatera Utara, 5) Pewarnaan Pada Master Desain, 6) Gambar Motif Kreasi Sumatera Utara pada Bahan Dasar Kain, 7) Material Dasar Kain Pada Pembuatan Kriya Tekstil Payet, 8) Bahan Payet Pada Pembuatan Kriya Tekstil Sumatera Utara, 9) Pengaplikasian Jenis-Jenis Payet Pada Bahan Dasar Kain, dan 10) Kreatifitas Mahasiswa Pembuatan Prodak kriya payet Sarung Bantal Kursi. Hasil data diatas menunjukkan bahwa pembelajaran praktek seni kriya payet tulis berbasis pada program studi tata busana Unimed mampu dikembangkan sesuai dibutuhkan masyarakat saat ini. Prodak baru seni kriya yang diciptakan oleh mahasiswa pendidikan tata busana unimed pada tahun 2016 berangkat dari budaya Sumatera Utara yang terdiri dari lima suku Batak. Kemudian hasil budaya Sumatera Utara dikembangkan pada lenan rumah tangga khususnya pada prodak sarung batal kursi tamu.

Indikator dari 1) Konsep Perancangan Kriya Payet sarung bantal kursi, 2) Prinsip-Prinsip Desain Pada Kreasi Motif Khas Sumatera Utara, 3) Sketsa Gambar Motif, 4) Kertas Gambar untuk Master Desain motif Sumatera Utara, 5) Pewarnaan Pada Master Desain, 6) Gambar Motif Kreasi Sumatera Utara pada Bahan Dasar Kain, 7) Material Dasar Kain Pada Pembuatan Kriya Tekstil Payet, 8) Bahan Payet Pada Pembuatan Kriya Tekstil Sumatera Utara, 9) Pengaplikasian JenisJenis Payet Pada

Mahasiswa Pembuatan Prodak kriya payet Sarung Bantal Kursi masuk dalam kategori baik dan memuaskan. Sehingga seluruh indikator diatas menunjukkan persiapan mahasiswa terhadap lapangan kerja dengan seoptimal

Bahan Dasar Kain, dan 10) Hasil Kreatifitas mungkin sebagai calon pengusaha kriya memayet ataupun desainer kriya. Dengan harapan setelah menyelesaikan studi di Perguruan Tinggi, mahasiswa siap memasuki dunia kerja dan mahasiswa siap membuka lapangan kerja baru di dunia usaha kriya payet sarung bantal kursi pada lenan rumah tangga yang sesuai dengan trend mode dan kebutuhan masyarakat masa kini.

\section{KESIMPULAN}

Hasil Evaluasi Pembelajaran Praktek Seni Kriya Payet Sarung Bantal Kursi Pada Program Studi Tata Busana Universitas Negeri Medan Unimed menunjukkan peningkatan kualitas sangat baik dengan hasil belajar mahasiswa yang baik pada program studi tata busana. Evaluasi kemampuan pembelajaran praktek pada mata kuliah seni kriya menggunakan metode penelitian deskripsi kualitatif dengan menggunakan Skala Liker . 
Hasil evaluasi ini terdiri dari sepuluh indikator yaitu; 1) Konsep Perancangan Seni Kriya Payet sarung bantal kursi Pada Program Studi Tata Busana Unimed dengan persentase $71 \%$. 2) PrinsipPrinsip Desain Pada Kreasi Motif Khas Sumatera Utara pada pembelajaran praktik seni kriya dengan presentase $71 \%$. 3) Sketsa Gambar Motif masuk kategori sedang dengan presentasi 77 \%. 4) Kertas Gambar untuk Master Desain motif Sumatera Utara termasuk kategori sedang dengan presentasi 75\%. 5) Pewarnaan Pada Master Desain masuk katergori tinggi dengan presentasi 80\%. 6) hasil Gambar Motif Kreasi Sumatera Utara pada Bahan Dasar Kain termasuk kategori sedang dengan presentase $75 \%$. 7) Material Dasar Kain Pada Pembuatan Kriya Tekstil Payet masuk ketegori sangat sedang dengan presentasi 76\%. 8) Bahan Payet Pada Pembuatan Kriya Tekstil Sumatera Utara termasuk kategori tinggi dengan presentase 81\%.9)

Pengaplikasian Jenis-Jenis Payet Pada Bahan Dasar Kain termasuk kategori sangat tinggi dengan presentase $81 \%$. Dan 10) Hasil Kreatifitas Mahasiswa Pembuatan Prodak kriya payet Sarung Bantal Kursi pada tahun 2016 masuk kategori tinggi dengan presentase $84 \%$.

Maka evaluasi pembelajaran praktek seni kriya memayet sarung bantal kursi pada lenan rumah tangga untuk mahasiswa guna mempersiapkan keterampilan dan pengetahuan dalam berwirausaha membuka lapangan kerja, seperti home industri.

Harapan pada mahasiswa yang telah mengikuti mata kuliah praktek seni kriya memayet pada lenan rumah tangga, kiranya mampu mengembangkan kreatifitas dalam menciptakan prodak seni kriya payet yang dibutuhkan masyarakat dimasa kini. Sehingga keterampilan yang diperoleh mahasiswa lebih eksis dalam menciptakan prodak seni kriya khas budaya Sumatera Utara / Indonesia hingga ke mancanegara.

\section{DAFTAR PUSTAKA}

Gie, Liang, 1996, Filsafat Keindahan, Yogyakarta, Pusat Belajar Ilmu Berguna (PUBIB).

Evaluasi Pembelajaran Praktek Seni Kriya Payet Sarung Bantal Kursi Pada Program Studi Tata Busana Universitas Negeri Medan - Netty Juliana
Haldani, achmad, 2007, Diktat Craft World, Bandung, FSRD ITB.

Soekanto, Soerjono, 1982, Suatu Penghantar Sosiologi, Jakarta, CV.Rajawali.

Sumardjo, Jakob, 2000, Filsafat Seni, Bandung, Percetakan ITB.

Sumardjo, Jakob, 2006, Estetika Paradoks, Bandung, Sunan Ambu Press.

Suyanto, 2013, Menjadi Guru Profesional Strategi Meningkatkan Kualifikasi \& Kualitas Guru Di Era Global, Jakarta, Penerbit Erlangga.

5) Widagdo, 2001, Desain dan Kebudayaan, Bandung, Depdiknas.

http://blogsenirupa.blogspot.co.id/2013/08/se ni-kriya.html

http://goesmul.blogspot.co.id/2012/03/senigrafis.html 